\title{
The antibody response to Plasmodium falciparum: cues for vaccine design and the discovery of receptor-based antibodies
}

\author{
Joshua Tan ${ }^{1,2}$, Luca Piccoli $^{1}$ and Antonio Lanzavecchia ${ }^{1,3}$, \\ ${ }^{1}$ Institute for Research in Biomedicine (IRB), Università della Svizzera italiana, 6500 Bellinzona, Switzerland \\ email: lanzavecchia@irb.usi.ch \\ ${ }^{2}$ Radcliffe Department of Medicine, John Radcliffe Hospital, University of Oxford, Oxford, UK \\ ${ }^{3}$ VIR Biotech, San Francisco, CA, USA
}

Keywords: malaria, sporozoites, monoclonal antibodies, vaccines, antibody diversification, receptor-based antibodies

\begin{abstract}
P. falciparum remains a serious public health problem and a continuous challenge for the immune system due to the complexity and diversity of the pathogen. Recent advances from several laboratories in the characterization of the antibody response to the parasite have led to the identification of critical targets for protection and revealed a new mechanism of diversification based on the insertion of host receptors into immunoglobulin genes, leading to the production of receptor-based antibodies. These advances have opened new possibilities for vaccine design and passive antibody therapies to provide sterilizing immunity and control blood-stage parasites.
\end{abstract}

Making unescapable antibodies. Polymorphic residues represent a powerful mechanism for the parasite to escape the antibody response, while retaining critical contact sites with human receptors. The finding that human receptor domains can be inserted into antibody genes defines a new type of receptor-based antibody that is in principle "unescapable". Once inserted into an antibody gene, the receptor domains can further evolve by losing self-reactivity and increasing binding to the pathogen. This is a remarkable example of "molecular bricolage" in somatic cells. 


\section{INTRODUCTION}

Malaria is caused by unicellular Plasmodium protozoan parasites that are injected by female Anopheles mosquitoes. P. falciparum, which causes the most severe form of malaria, is a substantial threat today, causing more than 200 million clinical cases and 400,000 deaths in 2016 (1). While the level of malaria has dropped over the last 15 years, this decline has stalled recently, with some regions experiencing a resurgence in the number of malaria cases $(1,2)$. Worryingly, resistance to artemisinin-based combination therapy (ACT), the current frontline treatment for malaria, is emerging in regions of Southeast Asia (3-5). These issues highlight the need for new means of prophylaxis and therapy, in particular an effective vaccine that can induce a potent anti-parasitic immune response, but this has proven to be a challenging task.

With over 5000 genes and thousands of years of evolution, $P$. falciparum poses a forbidding challenge to the human immune system $(6,7)$. There are two major aspects of the parasite life cycle (Figure 1) that frustrate the immune response. The first is the fact that the infecting agent, the sporozoite, is introduced in minute amounts and travels quickly to the liver to give rise to blood stage parasites that express a different set of genes. In this way, the sporozoite provides the parasite with a kind of stealth mechanism. The second is that in the blood stage, $P$. falciparum uses its substantial arsenal of antigens to frustrate the immune system in many ways, including using polymorphism and polygenicity to facilitate immune evasion, forming many (often redundant) interactions with host receptors for invasion or escape from clearance, and directly or indirectly inhibiting the immune response (8-13).

The complex multi-stage life cycle can be bewildering, but if broken down to its individual components, it also means that effective blockade of any one step by the immune system would eliminate the infection or at least ameliorate disease. The human body does make a response against most stages of the parasite life cycle, with both innate (monocytes, NK cells) and adaptive (B and T cells) components playing a role. This review will only focus on the antibody response - for detailed information on the other components of the immune system, we refer you to excellent reviews on these topics $(12,14,15)$. Nevertheless, any of these responses (or the sum of them) do not appear to be sufficient to provide sterile immunity, even in the face of multiple infections over many years. Adults living in malaria-endemic areas with a long history of malaria infection often remain free from malaria symptoms while remaining susceptible to infection (15). A large component of this immunity to disease is antibody-mediated, as the transfer of antibodies from semi-immune adults to children who have not yet developed antidisease immunity can greatly reduce parasite burden and malaria symptoms (16-18).

In the last decade, there has been a wave of studies reporting the isolation of monoclonal antibodies from vaccinated or naturally exposed individuals against various infectious agents. Combined with structures of key antibody-antigen complexes, these studies have the potential to revolutionize the field by allowing us to study antibody function at an unprecedented resolution. The potent and broadly reactive antibodies isolated can be used directly to prevent or control disease, an approach that is facilitated by new cost-effective ways of antibody delivery and by antibody engineering to increase effector function $(19,20)$. Monoclonal antibodies have also contributed a new approach to vaccine design. Neutralizing antibodies can be used to identify specific conformations of target antigens that can then be "locked" into place by biochemical modification and used as potent immunogens $(21,22)$. Furthermore, in the case of complex agents, an antigen-agnostic approach allows, through the isolation of monoclonal antibodies, the identification of the Achilles' heel of the pathogen by a process of analytic vaccinology (23). 
In the past few years, several laboratories have started using this approach to shed light on the complex antibody response to malaria parasites. This work has already begun to bear fruit, with new sites of vulnerability identified on decades-old vaccine candidates, a deeper insight gained on how the antibody response develops and matures in response to vaccination, and the discovery of the surprising biology and activity of receptor-based antibodies against bloodstage parasites. In this review, we will focus on the findings of these studies. We will discuss the antibody responses to the sporozoite stage and to the blood stage in separate sections, as each stage uses different strategies to survive and requires unique types of antibody responses for parasite elimination.

\section{THE ANTIBODY RESPONSE TO SPOROZOITES}

Conceptually, sporozoites represent an attractive target for antibody-mediated clearance as they represent a bottleneck in terms of numbers in the parasite life cycle, and elimination of parasites at this stage would prevent infection, disease and transmission. However, although antibodies against sporozoites induced by natural infection have been isolated $(24,25)$, there is little evidence for natural sterile immunity against sporozoite stages $(26,27)$. This could be due to the fact that there is a muted response due to the small inoculum, as well as potential immune suppression by blood-stage parasites (28-31). Furthermore, sporozoites take a short period of time (timeframe of hours) to reach and invade the liver (32), which means that there is probably insufficient time for memory B cells to differentiate and mount an antibody response. Therefore, protection is likely to rely on existing serum antibodies produced by longlived plasma cells. Although this antibody response increases with malaria exposure, it is substantially weaker than the response to blood-stage antigens and may not reach sufficient levels for protection $(25,33)$. Only a single sporozoite needs to escape the antibody response to trigger infection, suggesting that a robust, ever-vigilant immune response is needed for rapid elimination of sporozoites. Various attempts have been made to develop a vaccine that can generate such a response.

\section{Sporozoite-based vaccines}

Key studies in the 1960s and 1970s indicated that immunization of animal models or individuals with large numbers of irradiated sporozoites (>1000 mosquito bites) could induce sterile protection (34-37), providing a rationale for the development of a sporozoite-based vaccine. Both whole-sporozoite and subunit antigen vaccines have been attempted by different groups and are currently leading malaria vaccine candidates (38-40). With regard to subunit antigens, the most widely studied and prominent vaccine candidate is the circumsporozoite protein (CSP), which is an immunodominant antigen that coats the sporozoite surface and that plays a role in sporozoite migration and invasion of hepatocytes (41-48). P. falciparum CSP (PfCSP) contains an N-terminus that aids attachment to host cells, a central region consisting of NANP (and NVDP) repeats that is immunodominant for antibodies, and a C-terminus that contains T cell epitopes (Figure 2a).

The NANP repeat region has attracted a lot of attention, as it represents the core of the molecule, is conserved in different strains, and can elicit antibodies that are protective in in vitro and in vivo models (49-52). RTS,S, the most advanced malaria vaccine candidate, contains a portion of this repeat region, along with the $\mathrm{C}$-terminus to stimulate $\mathrm{T}$ cell help. 
However, RTS,S has only shown limited and transient efficacy, which has been attributed to the need to induce very high level of antibodies and maintain them over time (53-56). The need for high antibody titers could be explained by the quick passage of sporozoites into the liver and the requirement to block every single sporozoite, but it is also possible that many of these antibodies may not bind to PfCSP at relevant regions or in a way that interferes with function. PfCSP undergoes conformational shifts throughout the life cycle of the parasite and undergoes cleavage to unveil important epitopes prior to invasion $(46,48)$. Therefore, it may be important for a PfCSP-based malaria vaccine to induce antibodies that bind to PfCSP in specific conformations that are only unveiled for short periods of time. The design of such a vaccine would be greatly aided by the identification of potent monoclonal antibodies that bind to this antigen at these critical junctures. Besides PfCSP, other antigens that have been considered as vaccine candidates include thrombospondin-related adhesion protein (PfTRAP) (57-59) and cell-traversal protein for Plasmodium ookinetes and sporozoites (PfCelTOS) (60-62). These antigens are currently being investigated for suitability as vaccine candidates, and it would be interesting to isolate human monoclonal antibodies against these antigens to test their ability to block sporozoite invasion.

The development of the ability to manufacture large numbers of aseptic, purified and cryopreserved sporozoites (63) has paved the way for a series of recent clinical trials using radiation-attenuated sporozoites (PfSPZ Vaccine) or live sporozoites administered with chloroquine chemoprophylaxis (PfSPZ-CVac) as immunogens. These studies offer the distinctive advantage of providing all relevant antigens to stimulate an immune response. Overall, these trials have reported high levels of protection, particularly in malaria-naïve volunteers (64-68). It is still unclear whether antibodies play a role in the protected volunteers, but these studies have provided essential material for the isolation of human monoclonal antibodies as discussed below.

\section{Vaccine-induced monoclonal antibodies reveal susceptibility sites}

A series of recent studies has taken a deeper look at the antibody response to sporozoites by isolating a panel of human monoclonal antibodies from naturally infected individuals (25) or individuals vaccinated with RTS,S $(69,70)$, PfSPZ Vaccine $(71,72)$ or PfSPZ-CVac (73-75). While most researchers used PfCSP binding as the selection criterion to isolate antibodies, one study took an antigen-agnostic approach and searched for antibodies capable of staining intact sporozoites regardless of antigen specificity. Strikingly, this approach led to the isolation of a panel of antibodies that were all PfCSP-specific, confirming the immunodominance of this protein on the sporozoite surface $(51,71,76,77)$. Collectively, antibodies against the $\mathrm{N}$ terminus, NANP repeat region and C-terminus of PfCSP have been isolated from these studies. This body of work has shown that not all antibodies against PfCSP are equally protective - for instance, rare antibodies were isolated against the C-terminus of PfCSP, but these antibodies were not potent in in vitro assays and in a mouse model, perhaps due to the inaccessibility of this region on native PfCSP (73). A large number of monoclonal antibodies against the classical NANP repeats have also been isolated (70-75). Many of these antibodies were able to inhibit sporozoite invasion in in vitro and in vivo models using either a recombinant mouse malaria parasite $(P$. berghei) expressing PfCSP, or liver-humanized mice allowing mosquito-bite infection with P. falciparum. Moreover, crystal structures of several of these antibodies in complex with sections of the repeat region were solved, providing deeper insight into how the antibodies interact with PfCSP $(25,70,72,75)$. 
Two recent studies have identified a panel of antibodies that could bind to a unique junctional epitope between the NANP repeats and the N-terminus of PfCSP and that were more potent than the traditional NANP repeat antibodies in in vivo models $(71,72)$. In one case, a head-tohead comparison of two antibodies that originated from the same B cell clone and thus had similar sequences was conducted (71). Both antibodies could bind with similar affinities to sporozoites, whole PfCSP and the NANP repeat region, but only one antibody could also bind to the junctional epitope. This antibody was substantially more potent in the in vivo assay, suggesting that binding to this junctional epitope was key for its increased potency. This superior potency was also seen in other anti-junction antibodies isolated in the same study and in an anti-junction antibody identified by a different group, further highlighting the importance of this region $(71,72)$. The increased efficacy of these antibodies may have arisen from interference with cleavage of the N-terminus of PfCSP, which relies on a key conserved sequence (KLKQP) that is located upstream of their binding site and which is a key step before sporozoite invasion of hepatocytes $(46,72)$. Furthermore, the junctional epitope targeted by these antibodies is highly conserved in diverse $P$. falciparum isolates, suggesting its suitability as a vaccine candidate (72). The fact that the antibodies binding to the $\mathrm{N}$-terminal junction were isolated from both malaria-naïve and malaria-exposed vaccinated individuals provides a proof of concept that a vaccine can elicit such antibodies in individuals with diverse genetic backgrounds and different levels of prior malaria exposure. Notably, the $\mathrm{N}$-terminal junction is not included in the current form of the RTS,S vaccine, suggesting that the vaccine may be improved by adding this region.

Another striking finding from these studies is that $\operatorname{IgM}$ is a significant component of the human immune response to natural sporozoite infection (25) and dominates the memory B cell response even after several rounds of vaccination with PfSPZ Vaccine or PfSPZ-CVAC, indicating incomplete class switching despite repeated immunization $(71,74,78)$. The substantial IgM response may reflect the stimulation of splenic marginal zone B cells after vaccination with particulate antigens such as sporozoites, which carry numerous copies of PfCSP on the surface, each containing many NANP repeats (79). These IgM antibodies carry fewer, but still substantial, somatic mutations than their IgG counterparts, further supporting their origin from memory B cells $(71,74)$. As IgM activity is mainly restricted to the blood, these antibodies may act to capture sporozoites en route to the liver and disable the parasites through neutralization and complement fixation.

The monoclonal antibodies that have been isolated from vaccinated and naturally infected individuals as described above have provided sterile immunity in animal models, suggesting that if present in the right quantities, antibodies could play a protective role. However, at least in the case of the naturally infected individuals, these antibodies probably did not provide sterile protection in those individuals, reflecting the fact that immunity requires both the right antibody specificity and a sufficient antibody quantity. Therefore, a logical next step would be to test the ability of the best of these antibodies to prevent infection in humans, either in a controlled human malaria infection (CHMI) or in a natural infection setting. This study would help us to understand if the animal models recapitulate the conditions of sporozoite infection in humans. Furthermore, this would determine if antibodies alone can be protective in humans, and if so, the quantity of antibodies required for sterile protection. The results of this study would aid in the discussion of whether using monoclonal antibodies for passive vaccination against malaria is a realistic prospect.

\section{Lineage development and polymorphism}


It has become increasingly recognized that the study of the B cells that initiate a potent antibody response and the shared characteristics of these potent antibodies may aid in the development of a vaccine that aims to elicit such a response. The acquisition of the sequences of a large panel of anti-PfCSP monoclonal antibodies provides a unique opportunity to do so. One of the most interesting features shared by the most potent neutralizing antibodies that bind to the PfCSP N-terminal junction is that they are encoded by VH3-30/VH3-33 alleles carrying a tryptophan at position 52 (Figure 2b) (71). An investigation of the putative germline versions of these antibodies revealed that they originated as NANP repeat-binders and acquired binding to the N-terminal junction (along with higher affinity for NANP) through somatic mutations. Interestingly, while these antibodies were isolated from malaria-exposed individuals immunized with PfSPZ Vaccine, studies by other research groups on malaria-naïve individuals vaccinated with RTS,S or with PfSPZ-CVac also reported the identification of VH3-30/VH333 antibodies carrying Trp-52, further confirming the central role of these alleles in initiating the anti-PfCSP response $(66,70,74,80)$. Structural and mutational studies have confirmed that Trp-52 plays a key role in the interactions with NANP and the N-terminal junction. Furthermore, antibodies carrying the VK1-5 light chain have been isolated in all of these studies and was a dominant feature in the individuals vaccinated with PfSPZ-CVac $(70,71,74$, 75). Taken together, these studies suggest that regardless of prior malaria exposure and the exact immunogen used, many of the antibodies that target PfCSP, including potent antibodies that bind to a unique junctional epitope, share a common lineage and can be readily induced by vaccination. It remains to be established whether the lack of protection following PfSPZ vaccination observed in some individuals is due to the absence of the right VH3-30/VH3-33 allele or to an insufficient level or low affinity of the antibodies produced. These individuals should be analyzed to establish whether there are alternative antibody lineages that can control infection. For instance, monoclonal antibodies that do not use VH3-30/33 but have potent in vivo function have also been isolated $(25,72)$, suggesting that there are alternative solutions to generate potent neutralizing antibodies. Moreover, as the use of VH3-30/VH3-33 alone seems to be insufficient for potency without the right somatic mutations, it remains to be seen whether a single or multi-step vaccine can be designed to shepherd antibody maturation down a path that leads to the production of potent antibodies. It is likely that tools such as BCR-transgenic $B$ cells and structure-based design will be key elements to aid the development of such a vaccine.

\section{THE ANTIBODY RESPONSE TO BLOOD-STAGE PARASITES}

Individuals who live in malaria-endemic areas and are exposed to multiple infectious bites yearly gradually acquire immunity to clinical symptoms $(12,15)$. Seminal studies in the $1960 \mathrm{~s}$ and subsequent follow-up work demonstrated that antibodies play a large role in this protection, as antibodies from semi-immune adults could protect children from ongoing blood-stage disease, even when they were from distant malaria-endemic regions (16-18). However, given the vast array of antigens expressed by the merozoite and infected erythrocyte stages of the parasite life cycle, it has proven difficult to determine which antigens are important for this protective effect. Furthermore, while antibodies in naturally exposed individuals can suppress disease, they are thought to be unable to completely eliminate the parasites from the human host (27). Nevertheless, recent findings have offered hope that anti-merozoite vaccine candidates have the potential to block infection and confer protection, while vaccines that target infected erythrocytes are being developed to protect against specific forms of malaria such as pregnancy-associated malaria. In this section, we will discuss the antibody response to these 
asexual blood stages, along with a brief discussion of antibodies to gametocytes and subsequent sexual stages of the life cycle, which may be able to block malaria transmission.

\section{Antibodies that block erythrocyte invasion}

Antibodies that target merozoites are appealing tools to combat malaria as they have the potential to block merozoite invasion of erythrocytes, thus preventing infection, disease and eventually transmission. Malaria-exposed individuals generate robust antibody responses against merozoite antigens, and the breadth of this antibody response has been associated with protection against clinical malaria (81-83). Furthermore, human monoclonal antibodies against several merozoite antigens have been isolated, with some of these antibodies shown to have anti-parasitic activity in vitro (84-86). For instance, a monoclonal antibody that bound to the FC27 allelic family of the merozoite surface antigen PfMSP2 mediated phagocytosis not only of schizonts expressing the FC27 allele, but also of schizonts expressing the other major PfMSP2 allelic family 3D7 (85). Accordingly, a lot of attention has been given to prominent merozoite surface or apical antigens as vaccine candidates, including PfMSP1, PfMSP2, PfMSP3 and PfAMA1 (38). Unfortunately, clinical trials testing these antigens as vaccines have generally reported poor efficacy, particularly in malaria-exposed cohorts $(38,40,87,88)$. Several factors may limit the in vivo efficacy of anti-merozoite antibodies. Merozoites only require a short time (seconds to minutes) to invade erythrocytes, leaving only a small window for antibodies to act (89-91). This difficulty is compounded by the storage of many key invasion antigens in apical organelles such as micronemes and rhoptries, with are only released to the surface at the required stage of invasion $(87,92)$. As with PfCSP, some of these antigens are processed during the invasion process and thus conceal key epitopes until the required moment (93). Furthermore, many of these antigens are redundant for invasion and display high levels of polymorphism. Therefore, antibodies that only neutralize specific antigen subtypes may not be effective against diverse strains, which could be a serious problem given that multiple genotypes are often present, even in a single infection (94-96). These problems are exacerbated by the lack of reliable in vitro assays that offer a consistent correlate of protection. The growth inhibition assay, which measures the ability of antibodies to prevent asexual replication of parasites, does not always correlate with protection (97). Alternative in vitro assays that are being developed to complement the growth inhibition assay and that may be useful in the analysis of anti-merozoite antibody responses include antibody-dependent respiratory burst (98-100), antibody-dependent cellular phagocytosis (101), and complementbased assays (102).

Recently, there has been a resurgence of interest in merozoite antigens as vaccine candidates due to the discovery of the conserved antigen PfRH5, which overcomes many of the issues described above (103). PfRH5 is essential for blood-stage replication, is conserved in diverse $P$. falciparum strains, and is non-redundant, as its engagement with the host receptor basigin is required for merozoite invasion of erythrocytes (103-108). PfRH5 acts in a complex with other merozoite proteins including PfRipr, PfCyRPA and PfP113 (109-112), which may represent additional candidates for disease-controlling antibodies. Although there is a muted antibody response to PfRH5 in naturally exposed individuals, the level of antibodies, when present, is associated with protection against malaria $(113,114)$. Furthermore, vaccination of Aotus monkeys with PfRH5 led to high levels of protection against challenge with a heterologous parasite strain, which was correlated with antibody activity against PfRH5 in the growth inhibition assay (115). Another merozoite antigen that has received renewed attention is PfAMA1 in complex with its ligand, PfRON2, which is appended by the parasite to target 
erythrocytes. While clinical trials with PfAMA1 alone reported low levels of protection, recent studies have found that immunization with this paired complex conferred protection in mice and Aotus monkeys $(116,117)$. The enhanced effect has been associated with a shift in the quality of the anti-PfAMA1 antibodies, which more efficiently inhibit parasite replication in vitro. Taken together, PfRH5 and PfAMA1-PfRON2 offer promising targets to investigate with monoclonal antibodies, as protection associated with these antigens appears largely antibodydriven and antibody downselection is aided by the existence of in vitro assays that predict in vivo efficacy. Furthermore, the low level of naturally induced antibodies to PfRH5 suggests that the parasite acts to shield this antigen from the immune system, and that this antigen may be a good vaccine candidate if potent neutralizing antibodies can be elicited.

\section{Antibodies that block transmission}

Antibodies that target gametocytes and subsequent sexual stages are not able to block infection or disease, but have the potential to stop malaria transmission. Recently, there has been increasing interest in the use of antigens from these stages as candidates for a transmissionblocking vaccine (TBV) (118-120). Such a vaccine could induce antibodies that would be taken up with gametocytes during a mosquito blood meal and neutralize the parasites in the mosquito when the relevant antigens are unveiled. Key sexual stage antigens that have been considered as TBV candidates include Pfs48/45, Pfs230, Pfs 25 and Pfs47 (121-123). There is evidence that antibodies against these antigens, either from malaria-exposed individuals or vaccinated animals, could block the development of the parasites in mosquitoes (124-127). These findings offer an impetus to test human monoclonal antibodies against TBV antigens, such as those generated recently against Pfs25 (128), for the ability to block malaria transmission.

\section{Antibodies to infected erythrocytes}

During blood stage infection, $P$. falciparum conducts extensive remodeling of host erythrocytes and exports parasite antigens to the surface of the infected cells. Many of these antigens are encoded by large multigene families and are known as variant surface antigens (VSAs) due to their ability to be clonally expressed. The most prominent VSAs are Plasmodium falciparum erythrocyte membrane protein-1 (PfEMP1), repetitive interspersed family (RIFIN) and subtelomeric variant open reading frame (STEVOR) (129-133). Out of these protein families, PfEMP1 is by far the best characterized. Each P. falciparum genome contains about 60 PfEMP1 variants, and PfEMP1 expression is tightly controlled such that each infected erythrocyte only expresses a single variant at a time (134). Members of the PfEMP1 family have high molecular weights (200-350kDa) and contain multiple domains that target an array of host receptors including CD36, intercellular adhesion molecule-1 (ICAM1), vascular cell adhesion molecule-1 (VCAM1), platelet endothelial cell adhesion molecule-1 (PECAM1), chondroitin sulfate A (CSA) and endothelial protein C receptor (EPCR) (135137). The binding of PfEMP1 to these receptors allows the sequestration of infected erythrocytes in the microvasculature of multiple organs, which is thought to cause different forms of severe malaria. Accordingly, the type of PfEMP1 expressed by the infecting parasite strain has been linked to the severity of malaria (138). For instance, specific PfEMP1 domain combinations or "domain cassettes" (DC8 and DC13) have been linked to cerebral malaria through binding to EPCR, ICAM1 and $\mathrm{gC} 1 \mathrm{qR}$ on brain endothelial cells, resulting in infected erythrocyte blockage of the brain microvasculature and the stimulation of a pathological immune response $(137,139-144)$. Another striking example of the role of VSAs in disease can 
be seen in pregnancy-associated malaria, which may lead to fetal death in primigravid women $(145,146)$. This renewed pathogenicity is linked to the expression of a single conserved PfEMP1 variant, VAR2CSA, which binds to CSA in the placenta, allowing infected erythrocytes to colonize placental tissue $(135,147)$.

While PfEMP1 has been thoroughly studied for the past 30 years, less is known about STEVORs and RIFINs, which are expressed at multiple stages of the life cycle including in merozoites, gametocytes and sporozoites (148-152). STEVORs (30-40 variants per genome) have been reported to contribute to reduced deformability of infected erythrocytes and to bind to glycophorin $\mathrm{C}$ on the erythrocyte surface, mediating the binding of infected erythrocytes to uninfected erythrocytes to form so-called "rosettes" (153-155). RIFINs ( 150 variants per genome) form the largest VSA family in $P$. falciparum. Several variants have been reported to bind to blood group A antigens to facilitate rosetting (156), and recent studies have shown that other RIFIN variants bind to host inhibitory receptors, potentially mediating evasion of the immune response $(157,158)$.

Antibodies that target VSAs are key components of naturally acquired immunity to malaria, as parasites carrying specific VSAs are more likely to infect individuals who do not have antibodies against those variants $(159,160)$. In line with these findings, the acquisition of antibodies against specific types of PfEMP1 in children has been associated with protection against severe malaria (138). Additionally, in pregnancy-associated malaria, antibodies against VAR2CSA that are developed after the first pregnancy have been linked to protection against malaria during subsequent pregnancies $(135,161)$. A panel of monoclonal antibodies from multiparous women that bound selectively to CSA-adhering infected erythrocytes have been isolated and characterized (162). These antibodies were mapped to different domains of VAR2CSA, and several antibodies bound to infected erythrocytes from different parasite isolates and inhibited binding to CSA, supporting the feasibility of VAR2CSA-based vaccines against placental malaria $(163,164)$. It would be interesting to test the most potent monoclonal antibodies in animal models to obtain a proof of concept that antibodies alone can be protective in pregnancy-associated malaria.

Possible modes of action of antibodies against VSAs include the reversal of adhesion of infected erythrocytes to endothelium and uninfected erythrocytes (136), as well as the destruction of infected erythrocytes by the complement system (165), antibody-dependent cellular cytotoxicity (ADCC) (166) or opsonic phagocytosis (167). The protective efficacy of these antibodies is likely to be limited by the multigenicity and polymorphism of these antigen families, which allow the continuous emergence of variants that escape the immune response. Nonetheless, VSAs do not have unrestricted latitude to diversify, as they are constrained to preserve structural features that are required to bind to specific host receptors (168). Human monoclonal antibodies that recognize these regions can be used to identify the functional and thus most relevant domains, which can be formulated as vaccine candidates. These vaccines would have the advantage of focusing the antibody response onto the right targets while avoiding superfluous responses to decoy antigenic regions.

\section{A new class of receptor-based antibodies}

The polymorphism and clonal expression of VSAs offer a daunting challenge to the host immune response, as these antigens elicit antibodies that are predominantly specific for a given strain and are thus unable to control infection by other strains (169). A potential solution to this 
obstacle could be provided by the identification of broadly reactive antibodies, as recently done in HIV studies in which large-scale screenings allowed the identification of rare donors producing potent and cross-reactive neutralizing antibodies (20). To search for such antibodies, we screened plasma from 557 Kenyan donors for the ability to agglutinate mixtures of erythrocytes infected with different Kenyan $P$. falciparum isolates and identified three donors whose plasma formed mixed agglutinates with at least six isolates were identified $(157,169)$. Using a target agnostic approach, 30 monoclonal antibodies were isolated from two selected donors, with the majority binding to eight distinct parasite isolates and a few recognizing only a single isolate. Surprisingly, all the broadly reactive antibodies shared an unconventional gene structure containing an additional $400 \mathrm{bp}$ insert that encoded the extracellular domain of LAIR1, a collagen-binding inhibitory receptor encoded on Chr 19 (Figure 3a) $(157,170)$. Since the insertion occurred between the V and DJ segments, the inserted LAIR1 domain was expressed at the tip of the HCDR3 (Figure 3b) (171). This domain was both necessary and sufficient to bind to infected erythrocytes, as an irrelevant antibody containing an engineered LAIR1 insert and a LAIR1-Ig fusion protein both showed comparable binding to the cells. Importantly, the inserted LAIR1 domain acquired somatic mutations that abolished selfreactivity to collagen and increased affinity and cross-reactivity to different parasite isolates. Using a proteomics approach, specific members of the RIFIN family were identified as the target antigens of the LAIR1-containing antibodies. These antibodies were able to efficiently agglutinate infected erythrocytes and opsonize them for phagocytosis by monocytes, suggesting that they may aid parasite clearance. Taken together, these findings revealed, for the first time, the prototype of a new class of receptor-based antibodies that were generated by the insertion of a host receptor into the antibody gene.

To investigate how frequently receptor-based antibodies are produced in response to $P$. falciparum infection, a two-determinant immunoassay was used to screen plasma samples from 768 individuals living in Tanzania and Mali for the presence of LAIR1-containing antibodies (170). Up to $10 \%$ of the donors produced detectable levels of these antibodies, a frequency that is consistent with a "public" response. Subsequent work on selected donors led to the isolation of more than 50 LAIR1-containing monoclonal antibodies. While in four donors the antibodies shared the structure described above, in two other donors, the LAIR1 exon was inserted into the switch region together with flanking intronic sequences, thus preserving the splice sites. In the latter cases, splicing-in of the LAIR1 exon resulted in the expression of bispecific antibodies where the LAIR1 domain was precisely positioned at the elbow between the VH and $\mathrm{CH} 1$ domains (Figure 3a,b). In another case, a LAIR1 insertion into the switch region was accompanied by deletions of genomic DNA encoding $\mathrm{VH}$ and $\mathrm{CH} 1$ domains, resulting in a gene encoding a camel-like LAIR1-containing antibody. Collectively, these findings revealed a second mechanism of DNA insertion into the switch region that also resulted in the production of receptor-based antibodies and an overall prevalence of these antibodies that was close to $10 \%$ in malaria-exposed populations. Furthermore, through the design of different antibody constructs in which the LAIR1 domain was exchanged with different immunoglobulin-like domains such as SLAM or PD1, it was shown that the VH-CH1 elbow is a permissive site that may be suitable for engineering bispecific antibodies for therapeutic applications.

In all the individuals analyzed so far, the response to $P$. falciparum-infected erythrocytes was dominated by LAIR1-containing antibodies that were produced by a single expanded B cell clone, suggesting that chronic stimulation by malaria parasites can induce and sustain this type of antibody response in spite of an extremely low frequency of precursor cells $(n=1)(170)$. Importantly, as in the case of insertion in the VDJ regions, somatic mutations also occurred in 
LAIR1 inserted into the switch region, although at a lower frequency, and these mutations were able to abolish self-reactivity to collagen and modulate binding to infected erythrocytes. Taken together, these findings indicate that binding of the broadly reactive antibodies is strictly dependent on the mutated LAIR1 domain, which evolves under selective pressure to first lose self-reactivity and then gain affinity and breadth to infected erythrocytes. This observation is in line with the well-known role of somatic mutations in affinity maturation and in the redemption of self-reactive antibodies from autoreactivity (172). Of note, while LAIR1containing antibodies may help in opsonizing infected erythrocytes and in counteracting parasite evasion strategies by disrupting the interactions of RIFINs with inhibitory receptors on immune cells (Figure 3c), their efficacy may be limited in terms of protection from future infections as these antibodies recognize only a fraction of parasites expressing similar RIFINs and allow the selection of escape mutants expressing different RIFIN variants. Further studies analyzing the reactivity to autologous isolates isolated from individuals who produce LAIR1containing antibodies will help to better understand their role in protection or in controlling the infection in vivo.

Overall, these data suggest that exposure to malaria and the extensive use of human receptors by the parasites to modulate the immune response can lead to the selection of an unusual type of receptor-based antibody. Based on these observations, there is little reason to believe that this insertion pathway is limited to LAIR1. Given the vast array of receptors targeted by malaria parasites, it is conceivable that different types of receptor-based antibodies, such as those containing LILRB1 or ICAM1, may be discovered in the future.

\section{Future perspectives}

The recent discoveries on malaria antibodies represent a scientific breakthrough that have an impact on active and passive vaccination strategies, as well as on antibody biology. The availability of potent antibodies that block sporozoite infection suggests the possibility of achieving sterilizing immunity through passive vaccination. In this context it will be important to select the most potent antibodies that can be produced with appropriate Fc modifications to increase half-life and binding to $\mathrm{Fc}$ receptors on effector cells. This process is facilitated by the availability of a large panel of well-characterized antibodies that can be tested, alone or in combination, in animal models of infection and ultimately in human challenge studies to establish the dose required to achieve sterilizing protection.

Furthermore, these potent neutralizing antibodies provide a useful tool to identify the sites of vulnerability in PfCSP that may be absent in the current RTS,S vaccine. This discovery opens the possibility of developing a second-generation recombinant vaccine capable of inducing potent antibodies with dual specificity for the NANP repeat and the N-terminal junctional epitope through a prime-boost strategy with recombinant antigens. Transgenic B cells expressing the germline version of these antibodies represent an interesting tool to accelerate vaccine design through a germline-targeting strategy $(173,174)$. A similar approach of antibody-based vaccine design could be pursued to develop passive and active immunization strategies to control blood-stage parasites. For instance, antibodies that block binding of VAR2CSA could be used to prevent placental malaria and to design a protective recombinant vaccine that contains the most relevant domains.

The receptor-based antibodies discovered in malaria-exposed individuals have the distinctive property of binding to the pathogen through the same receptor that the pathogen uses to infect 
host cells. It is interesting to consider that this mode of interaction was anticipated by Paul Ehrlich in his side chain model of antibody formation. Interestingly, unlike conventional antibodies, receptor-based antibodies can bind to different allelic forms and may not allow the selection of escape mutants. Furthermore, through somatic mutations, receptor-based antibodies can further evolve the receptor domain to decrease self-reactivity and increase binding to the pathogen (BOX). The identification of LAIR1-based antibodies in $10 \%$ of malaria-exposed individuals and the frequent detection of templated inserts derived from all chromosomes in antibody genes of European blood donors (170) provide a stimulus to search for other examples. Finally, the novel structure of receptor-based antibodies provides a new therapeutic format that can be applied to engineer bispecific antibodies against different pathogens. 


\section{FIGURE LEGENDS}

Figure 1. The life cycle of $\boldsymbol{P}$. falciparum. This figure shows the different stages of the life cycle, along with several key parasite antigens that are potential antibody targets at each stage. A malaria infection begins when an infected female Anopheles mosquito injects a small number of sporozoites into the skin of a human host during a blood meal. The sporozoites enter blood vessels and home to the liver, where they invade target hepatocytes and develop into parasite liver stages, which subsequently rupture to release thousands of merozoites into the bloodstream. These merozoites invade erythrocytes and undergo asexual replication in these cells. A proportion of blood-stage parasites differentiate into male and female gametocytes, which are taken up by the mosquito during a blood meal. These gametocytes mature into gametes and fuse to become zygotes, which later develop into ookinetes and subsequently undergo meiosis to form sporozoites.

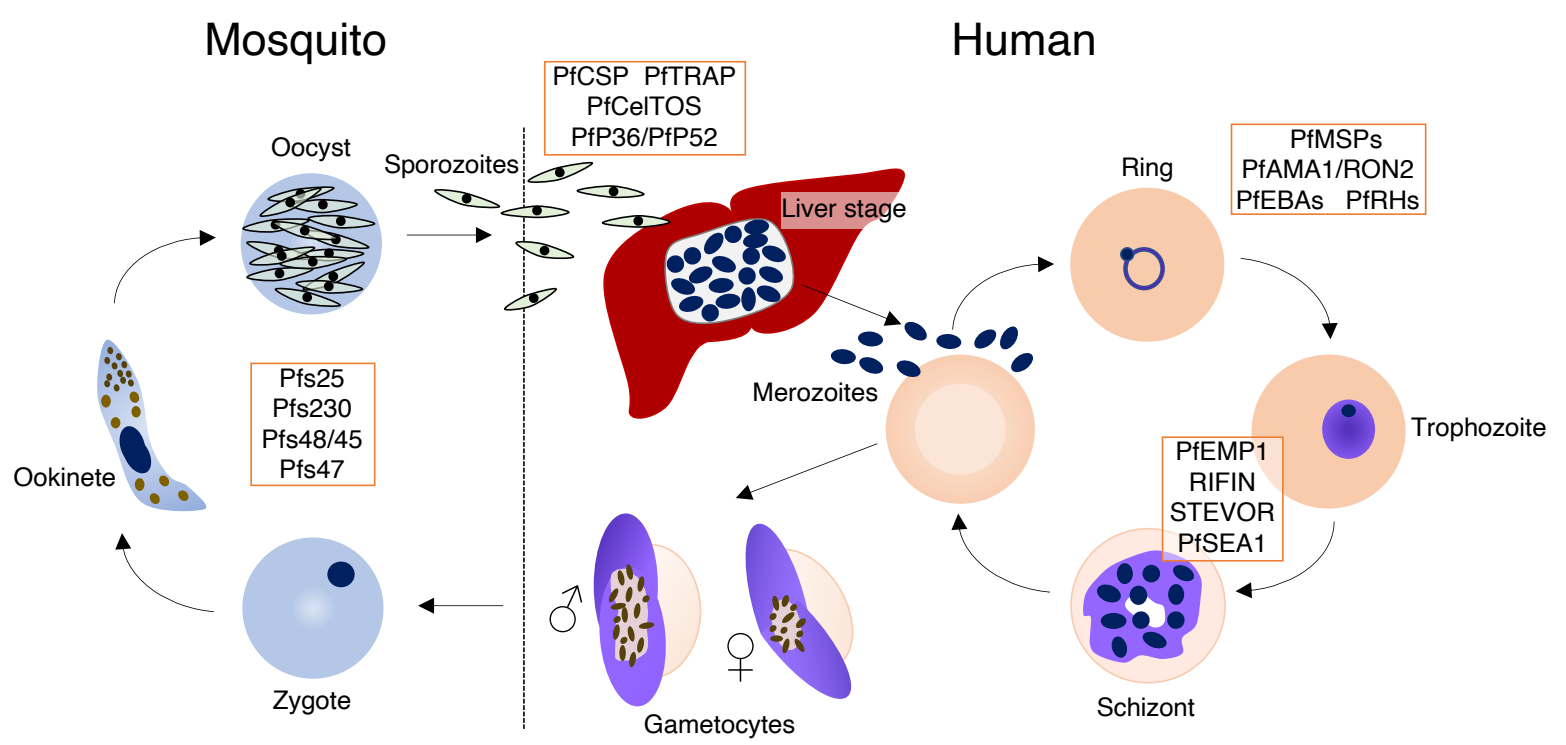


Figure 2. The antibody response to PfCSP. a) Schematic of PfCSP compared to RTS,S vaccine. b) Neutralization and binding of monoclonal antibodies to full PfCSP and to NANP and N-terminal junctional (NPDP) peptides. For purposes of comparison, only antibodies that have been tested both for binding to the PfCSP N-terminal junction and for in vivo efficacy are included in this table. A large panel of anti-NANP repeat monoclonal antibodies that have in vivo neutralizing function have also been isolated and characterized by other groups $(25,74)$.

a)

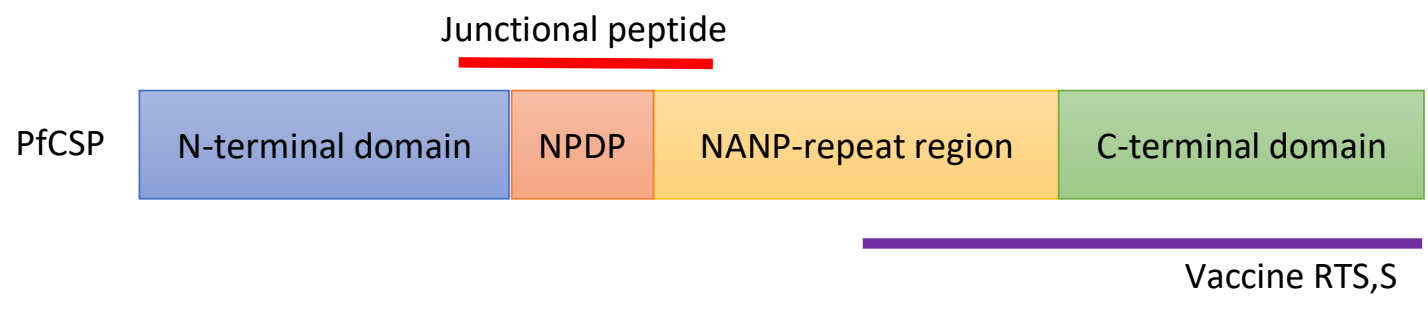

\begin{tabular}{|c|c|c|c|c|c|c|c|c|c|c|c|}
\hline \multirow{2}{*}{$\begin{array}{l}\text { Study } \\
\text { Tan et al. }\end{array}$} & \multirow{2}{*}{$\begin{array}{l}\text { mAb } \\
\text { MGU1 }\end{array}$} & \multicolumn{3}{|c|}{ Heavy chain VDJ genes } & \multicolumn{2}{|c|}{ Light chain VJ genes } & \multirow[t]{2}{*}{ PfSPZ } & \multirow[t]{2}{*}{ PfCSP } & \multirow[t]{2}{*}{ NPDP } & \multirow[t]{2}{*}{ NANP } & \multirow[t]{2}{*}{ Neutr. } \\
\hline & & VH3-30 ${ }^{f}$ & $D 2-21$ & $J H 3$ & VL4-69 & JL3 & & & & & \\
\hline & MGU10 & VH3-30 & D3-9 & JH3 & VL4-69 & JL3 & & & & & \\
\hline & MGG3 & VH3-30 $f$ & $D 7-27$ & $\mathrm{JH} 2$ & VK2-29 & $J K 1$ & & & & & \\
\hline & MGG4 & VH3-30 ${ }^{f}$ & D3-22 & $J H 3$ & $V K 4-1$ & JK4 & & & & & \\
\hline & MGH2 & VH3-30 ${ }^{f}$ & $D 7-27$ & $\mathrm{JH} 2$ & $V K 2-30$ & $J K 1$ & & & & & \\
\hline & MGU12 & VH3-30 & D3-16 & JH3 & $V K 1-5$ & $J K 1$ & & & & & \\
\hline & MGG8 & VH3-73 & $D 2-2$ & JH5 & VK2D-29 & $J K 1$ & & & & & \\
\hline & MGH1 & VH1-2 & D6-19 & JH4 & VK2-30 & $J K 2$ & & & & & \\
\hline & MGH3 & VH3-21 & D3-22 & JH4 & $V K 2-28$ & JK4 & & & & & \\
\hline Kisalu et al. & CIS43 & VH1-3 & D4-23 & JH3 & VK4-1 & JK4 & & & & & \\
\hline & CIS34 & VH3-33 & D6-13 & JH5 & VK1-39 & $J K 3$ & & & & & \\
\hline & CIS42 & VH7-4-1 & D5-18 & JH4 & VL2-23 & JL3 & & & & & \\
\hline & CIS23 & VH3-30 & D6-13 & JH4 & VK3-11 & $J K 2$ & & & & & \\
\hline & $\mathrm{mAb04}$ & VH3-33 & D3-22 & JH4 & VK2D-29 & $J K 2$ & & & & & \\
\hline & mAb09 & VH3-33 & D3-22 & JH3 & VK3-11 & $J K 3$ & & & & & \\
\hline & mAb10 & VH3-33 & D4-23 & $\mathrm{JH} 4$ & $V K 1-5$ & $J K 1$ & & & & & \\
\hline
\end{tabular}


Figure 3. Receptor-based antibodies selected by blood-stage parasites. a) LAIR1containing antibodies can help in controlling the malaria infection by binding to RIFINs expressed on the surface of infected erythrocytes. b) Two modalities of LAIR1 insertion into the VDJ region or into the switch region of immunoglobulin genes result in the production of receptor-based antibodies expressing a functional LAIR1 extracellular domain that is positioned at the tip of the HCDR3 or in the elbow between the VH and $\mathrm{CH} 1$ domains. c) RIFINs expressed on the surface of $P$. falciparum-infected erythrocytes can downregulate the immune response to the parasite by binding to inhibitory receptors expressed by different immune cells.
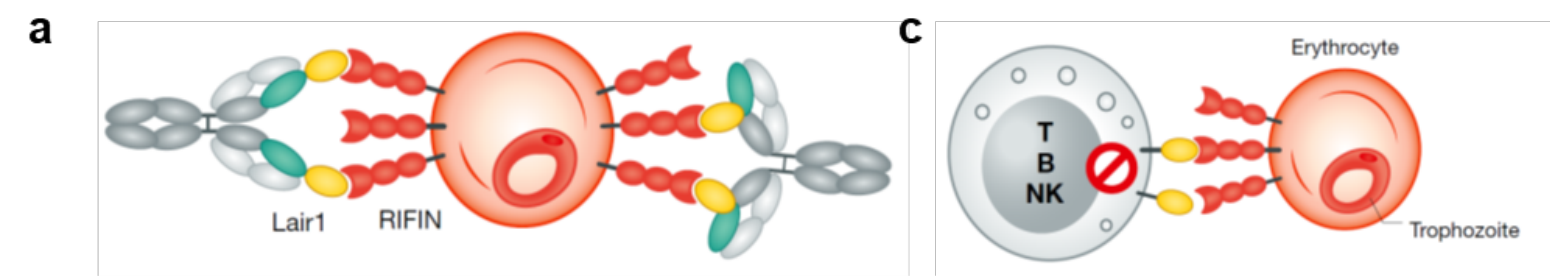

b

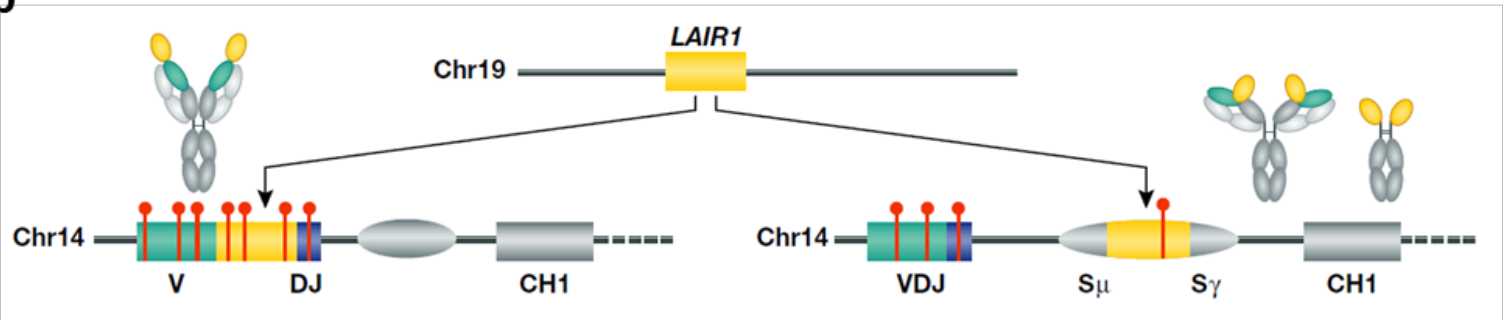




\section{REFERENCES}

1. World Health Organization. 2017. World malaria report 2017

2. Bhatt S, Weiss DJ, Cameron E, Bisanzio D, Mappin B, et al. 2015. The effect of malaria control on Plasmodium falciparum in Africa between 2000 and 2015. Nature. 526(7572):207-11

3. Tilley L, Straimer J, Gnädig NF, Ralph SA, Fidock DA. 2016. Artemisinin action and resistance in Plasmodium falciparum. Trends Parasitol. 32(9):682-96

4. Fairhurst RM, Dondorp AM. 2016. Artemisinin-resistant Plasmodium falciparum Malaria. In Emerging infections 10, pp. 409-29. American Society of Microbiology. $21 \mathrm{p}$.

5. Woodrow CJ, White NJ. 2017. The clinical impact of artemisinin resistance in Southeast Asia and the potential for future spread. FEMS Microbiol.Rev. 41(1):3448

6. Liu W, Li Y, Learn GH, Rudicell RS, Robertson JD, et al. 2010. Origin of the human malaria parasite Plasmodium falciparum in gorillas. Nature. 467(7314):420-25

7. Loy DE, Liu W, Li Y, Learn GH, Plenderleith LJ, et al. 2017. Out of Africa: origins and evolution of the human malaria parasites Plasmodium falciparum and Plasmodium vivax. Int J Parasitol. 47(2-3):87-97

8. Wright GJ, Rayner JC. 2014. Plasmodium falciparum erythrocyte invasion: combining function with immune evasion. PLoS Pathog. 10(3):e1003943-47

9. Kurup SP, Obeng-Adjei N, Anthony SM, Traore B, Doumbo OK, et al. 2017. Regulatory $\mathrm{T}$ cells impede acute and long-term immunity to blood-stage malaria through CTLA-4. Nat Med.23(10):1220-25

10. Yam XY, Preiser PR. 2017. Host immune evasion strategies of malaria blood stage parasite. Mol. BioSyst. 13(12):2498-2508

11. Portugal S, Obeng-Adjei N, Moir S, Crompton PD, Pierce SK. 2017. Atypical memory B cells in human chronic infectious diseases: an interim report. Cellular Immunology. 321:18-25

12. Crompton PD, Moebius J, Portugal S, Waisberg M, Hart G, et al. 2014. Malaria immunity in man and mosquito: insights into unsolved mysteries of a deadly infectious disease. Annu. Rev. Immunol. 32(1):157-87

13. Urban BC, Ferguson DJ, Pain A, Willcox N, Plebanski M, et al. 1999. Plasmodium falciparum-infected erythrocytes modulate the maturation of dendritic cells. Nature. 400(6739):73-77

14. Artavanis-Tsakonas K, Tongren JE, Riley EM. 2003. The war between the malaria parasite and the immune system: immunity, immunoregulation and immunopathology. Clin Exp Immunol. 133(2):145-52

15. Langhorne J, Ndungu FM, Sponaas A-M, Marsh K. 2008. Immunity to malaria: more questions than answers. Nat Immunol. 9(7):725-32

16. Cohen S, Carrington S, McGregor IA. 1961. Gamma-globulin and acquired immunity to human malaria. Nature. 192(480):733-37

17. McGregor IA, Carrington SP, Cohen S. 1963. Treatment of East African $P$. falciparum Malaria with West African human $\gamma$-globulin. Trans $R$ Soc Trop Med Hyg. 57(3):170-75

18. Sabchareon A, Burnouf T, Ouattara D, Attanath P, Bouharoun-Tayoun H, et al. 1991 . Parasitologic and clinical human response to immunoglobulin administration in falciparum malaria. Am J Trop Med Hyg . 45(3):297-308

19. Marston HD, Paules CI, Fauci AS. 2018. Monoclonal antibodies for emerging infectious diseases - borrowing from history. N Engl J Med.378(16):1469-72 
20. Walker LM, Burton DR. 2018. Passive immunotherapy of viral infections: "superantibodies" enter the fray. Nat Med. 18(5):297-308

21. Burton DR. 2017. What are the most powerful immunogen design vaccine strategies? Cold Spring Harb Perspect Biol. 9(11):a030262-69

22. Kwong PD. 2017. What are the most powerful immunogen design vaccine strategies? Cold Spring Harb Perspect Biol. 9(11):a029470-12

23. Lanzavecchia A, Frühwirth A, Perez L, Corti D. 2016. Antibody-guided vaccine design: identification of protective epitopes. Current Opin Immunol. 41:62-67

24. Offeddu V, Olotu A, Osier F, Marsh K, Matuschewski K, Thathy V. 2017. High sporozoite antibody titers in conjunction with microscopically detectable blood infection display signatures of protection from clinical malaria. Front Immunol. 8:209-12

25. Triller G, Scally SW, Costa G, Pissarev M, Kreschel C, et al. 2017. Natural parasite exposure induces protective human anti-malarial antibodies. Immunity. 47:1-13

26. Hoffman SL, Oster CN, Plowe CV, Woollett GR, Beier JC, et al. 1987. Naturally acquired antibodies to sporozoites do not prevent malaria: vaccine development implications. Science. 237(4815):639-42

27. Tran TM, Li S, Doumbo S, Doumtabe D, Huang CY, et al. 2013. An intensive longitudinal cohort study of Malian children and adults reveals no evidence of acquired immunity to Plasmodium falciparum infection. Clin Infect Dis. 57(1):40-47

28. Rosenberg R, Wirtz RA, Schneider I, Burge R. 1990. An estimation of the number of malaria sporozoites ejected by a feeding mosquito. Trans R Soc Trop Med Hyg. 84(2):209-12

29. Beier JC, Davis JR, Vaughan JA, Noden BH, Beier MS. 1991. Quantitation of Plasmodium falciparum Sporozoites transmitted in vitro by experimentally infected Anopheles gambiae and Anopheles stephensi. Am J Hyg Trop Med. 44(5):564-70

30. Medica DL, Sinnis P. 2005. Quantitative dynamics of Plasmodium yoelii Sporozoite transmission by infected anopheline mosquitoes. Infect Immun. 73(7):4363-69

31. Keitany GJ, Kim KS, Krishnamurty AT, Hondowicz BD, Hahn WO, et al. 2017. Blood stage malaria disrupts humoral immunity to the pre-erythrocytic stage circumsporozoite protein. Cell Rep, pp. 1-14

32. Vanderberg JP. 2014. Imaging mosquito transmission of Plasmodium sporozoites into the mammalian host: immunological implications. Parasitol Int. 63(1):150-64

33. Offeddu V, Thathy V, Marsh K, Matuschewski K. 2012. Naturally acquired immune responses against Plasmodium falciparum Sporozoites and liver infection. Int $J$ Parasitol. 42(6):535-48

34. Nussenzweig RS, Vanderberg J, Most H, Orton C. 1967. Protective immunity produced by the injection of X-irradiated sporozoites of Plasmodium berghei. Nature. 216(5111):160-62

35. Clyde DF, Most H, McCarthy VC, Vanderberg JP. 1973. Immunization of man against sporozoite-induced falciparum malaria. Am J Med Sci. 266(3):169-77

36. Rieckmann KH, Carson PE, Beaudoin RL, Cassells JS, Sell KW. 1974. Sporozoite induced immunity in man against an Ethiopian strain of Plasmodium falciparum. Trans R Soc Trop Med Hyg. 68(3):258-59

37. Hoffman SL, Goh LML, Luke TC, Schneider I, Le TP, et al. 2002. Protection of humans against malaria by immunization with radiation-attenuated Plasmodium falciparum sporozoites. J Infect Dis. 185(8):1155-64

38. Schwartz L, Brown GV, Genton B, Moorthy VS. 2012. A review of malaria vaccine clinical projects based on the WHO rainbow table. Malar J. 11(1):11 
39. Duffy PE, Sahu T, Akue A, Milman N, Anderson C. 2014. Pre-erythrocytic malaria vaccines: identifying the targets. Expert Rev Vaccines. 11(10):1261-80

40. Draper SJ, Sack BK, King CR, Nielsen CM, Rayner JC, et al. 2018. Malaria vaccines: recent advances and new horizons. Cell Host Microbe. 24(1):43-56

41. Yoshida N, Nussenzweig RS, Potocnjak P, Nussenzweig V, Aikawa M. 1980. Hybridoma produces protective antibodies directed against the sporozoite stage of malaria parasite. Science. 207(4426):71-73

42. Potocnjak P, Yoshida N, Nussenzweig RS, Nussenzweig V. 1980. Monovalent fragments $(\mathrm{Fab})$ of monoclonal antibodies to a sporozoite surface antigen $(\mathrm{Pb} 44)$ protect mice against malarial infection. J Exp Med.151(6):1504-13

43. Cerami C, Frevert U, Sinnis P, Takacs B, Clavijo P, et al. 1992. The basolateral domain of the hepatocyte plasma membrane bears receptors for the circumsporozoite protein of Plasmodium falciparum sporozoites. Cell. 70(6):1021-33

44. Frevert U, Sinnis P, Cerami C, Shreffler W, Takacs B, Nussenzweig V. 1993. Malaria circumsporozoite protein binds to heparan sulfate proteoglycans associated with the surface membrane of hepatocytes. J Exp Med. 177(5):1287-98

45. Dame JB, Williams JL, McCutchan TF, Weber JL, Wirtz RA, et al. 1984. Structure of the gene encoding the immunodominant surface antigen on the sporozoite of the human malaria parasite Plasmodium falciparum. Science. 225(4662):593-99

46. Coppi A, Pinzon-Ortiz C, Hutter C, Sinnis P. 2005. The Plasmodium Circumsporozoite protein is proteolytically processed during cell invasion. $J$ Exp Med. 201(1):27-33

47. Coppi A, Tewari R, Bishop JR, Bennett BL, Lawrence R, et al. 2007. Heparan sulfate proteoglycans provide a signal to Plasmodium Sporozoites to stop migrating and productively invade host cells. Cell Host Microbe. 2(5):316-27

48. Coppi A, Natarajan R, Pradel G, Bennett BL, James ER, et al. 2011. The malaria circumsporozoite protein has two functional domains, each with distinct roles as sporozoites journey from mosquito to mammalian host. J Exp Med. 208(2):341-56

49. Godson GN, Ellis J, Svec P, Schlesinger DH, Nussenzweig V. 1983. Identification and chemical synthesis of a tandemly repeated immunogenic region of Plasmodium knowlesi circumsporozoite protein. Nature. 305(5929):29-33

50. Zavala F. 1983. Circumsporozoite proteins of malaria parasites contain a single immunodominant region with two or more identical epitopes. J Exp Med. 157(6):1947-57

51. Zavala F, Tam JP, Hollingdale MR, Cochrane AH, Quakyi I, et al. 1985. Rationale for development of a synthetic vaccine against Plasmodium falciparum malaria. Science. 228(4706):1436-40

52. Zavala F, Tam JP, Barr PJ, Romero PJ, Ley V, et al. 1987. Synthetic peptide vaccine confers protection against murine malaria. J Exp Med. 166(5):1591-96

53. White MT, Bejon P, Olotu A, Griffin JT, Riley EM, et al. 2013. The relationship between RTS,S vaccine-induced antibodies, CD4+ T cell responses and protection against Plasmodium falciparum infection. PLoS ONE. 8(4):e61395-10

54. White MT, Verity R, Griffin JT, Asante KP, Owusu-Agyei S, et al. 2015. Immunogenicity of the RTS,S/AS01 malaria vaccine and implications for duration of vaccine efficacy: secondary analysis of data from a phase 3 randomised controlled trial. Lancet Infect Dis. 15(12):1450-58

55. RTSS Clinical Trials Partnership. 2015. Efficacy and safety of RTS,S/AS01 malaria vaccine with or without a booster dose in infants and children in Africa: final results of a phase 3, individually randomised, controlled trial. Lancet. 386(9988):31-45 
56. Dups JN, Pepper M, Cockburn IA. 2014. Antibody and B cell responses to Plasmodium sporozoites. 5:625

57. Sultan AA, Thathy V, Frevert U, Robson KJ, Crisanti A, et al. 1997. TRAP is necessary for gliding motility and infectivity of plasmodium sporozoites. Cell. 90(3):511-22

58. Ogwang C, Kimani D, Edwards NJ, Roberts R, Mwacharo J, et al. 2015. Prime-boost vaccination with chimpanzee adenovirus and modified vaccinia Ankara encoding TRAP provides partial protection against Plasmodium falciparum infection in Kenyan adults. Sci Transl Med.7(286):286re5

59. Rampling T, Ewer KJ, Bowyer G, Bliss CM, Edwards NJ, et al. 2016. Safety and high level efficacy of the combination malaria vaccine regimen of RTS,S/AS01 ${ }_{B}$ with chimpanzee adenovirus 63 and modified vaccinia Ankara vectored vaccines expressing ME-TRAP. J Infect Dis. 214(5):772-81

60. Kariu T, Ishino T, Yano K, Chinzei Y, Yuda M. 2006. CelTOS, a novel malarial protein that mediates transmission to mosquito and vertebrate hosts. Mol Microbiol. 59(5):1369-79

61. Bergmann-Leitner ES, Mease RM, La Vega PloS one De P, 2010. Immunization with pre-erythrocytic antigen CelTOS from Plasmodium falciparum elicits crossspecies protection against heterologous challenge with Plasmodium berghei. PLoS $O N E$

62. Espinosa DA, Vega-Rodriguez J, Flores-Garcia Y, Noe AR, Muñoz C, et al. 2017. The Plasmodium falciparum cell-traversal protein for ookinetes and sporozoites as a candidate for preerythrocytic and transmission-blocking vaccines. Infect Immun . 85(2):e00498-16-10

63. Hoffman SL, Billingsley PF, James E, Richman A, Loyevsky M, et al. 2010. Development of a metabolically active, non-replicating sporozoite vaccine to prevent Plasmodium falciparum malaria. Hum Vaccin. 6(1):97-106

64. Seder RA, Chang LJ, Enama ME, Zephir KL, Sarwar UN, et al. 2013. Protection against malaria by intravenous immunization with a nonreplicating sporozoite vaccine. Science. 341(6152):1359-65

65. Ishizuka AS, Lyke KE, DeZure A, Berry AA, Richie TL, et al. 2016. Protection against malaria at 1 year and immune correlates following PfSPZ vaccination. Nat Med. 22(6):614-23

66. Mordmüller B, Surat G, Lagler H, Chakravarty S, Ishizuka AS, et al. 2017. Sterile protection against human malaria by chemoattenuated PfSPZ vaccine. Nat Med. 542(7642):445-49

67. Sissoko M, Healy SA, Katile A, Omaswa F, Zaidi I, et al. 2017. Safety and efficacy of PfSPZ Vaccine against Plasmodium falciparum via direct venous inoculation in healthy malaria-exposed adults in Mali: a randomised, double-blind phase 1 trial. Lancet Infect Dis. 17:498-509

68. Jongo SA, Shekalage SA, Church LWP, Ruben AJ, Schindler T, et al. 2018. Safety, immunogenicity, and protective efficacy against controlled human malaria infection of Plasmodium falciparum Sporozoites vaccine in Tanzanian adults. Am J Trop Med Hyg

69. Foquet L, Hermsen CC, van Gemert G-J, Van Braeckel E, Weening KE, et al. 2013. Vaccine-induced monoclonal antibodies targeting circumsporozoite protein prevent Plasmodium falciparum infection. J. Clin. Invest. 124(1):140-44

70. Oyen D, Torres JL, Wille-Reece U, Ockenhouse CF, Emerling D, et al. 2017. Structural basis for antibody recognition of the NANP repeats in Plasmodium falciparum circumsporozoite protein. Proc Natl Acad Sci USA. 114(48):E10438-45 
71. Tan J, Sack BK, Oyen D, Zenklusen I, Piccoli L, et al. 2018. A public antibody lineage that potently inhibits malaria infection through dual binding to the circumsporozoite protein. Nat Med. 24(4):401-7

72. Kisalu NK, Idris AH, Weidle C, Flores-Garcia Y, Flynn BJ, et al. 2018. A human monoclonal antibody prevents malaria infection by targeting a new site of vulnerability on the parasite. Nat Med.24(4):408-16

73. Scally SW, Murugan R, Bosch A, Triller G, Costa G, et al. 2018. Rare PfCSP Cterminal antibodies induced by live sporozoite vaccination are ineffective against malaria infection. J Exp Med. 215(1):63-75

74. Murugan R, Buchauer L, Triller G, Kreschel C, Costa G, et al. 2018. Clonal selection drives protective memory B cell responses in controlled human malaria infection. Sci Immunol. 3(20):

75. Imkeller K, Scally SW, Bosch A, Martí GP, Costa G, et al. 2018. Antihomotypic affinity maturation improves human $\mathrm{B}$ cell responses against a repetitive epitope. Science. 360(6395):1358-62

76. Swearingen KE, Lindner SE, Shi L, Shears MJ, Harupa A, et al. 2016. Interrogating the Plasmodium sporozoite surface: identification of surface-exposed proteins and demonstration of glycosylation on CSP and TRAP by mass spectrometry-based proteomics. PLoS Pathog. 12(4):e1005606

77. Arun Kumar K, Sano G-I, Boscardin S, Nussenzweig RS, Nussenzweig MC, et al. 2006. The circumsporozoite protein is an immunodominant protective antigen in irradiated sporozoites. Nature. 444(7121):937-40

78. Zenklusen I, Jongo S, Abdulla S, Ramadhani K, Lee Sim BK, et al. 2018. Immunization of malaria-preexposed volunteers with PfSPZ vaccine elicits longlived IgM invasion-inhibitory and complement-fixing antibodies. J Infect Dis. 217(10):1569-78

79. Weill J-C, Weller S, Reynaud C-A. 2009. Human marginal zone B cells. Annu. Rev. Immunol. 27(1):267-85

80. Regules JA, Cicatelli SB, Bennett JW, Paolino KM, Twomey PS, et al. 2016. Fractional third and fourth dose of RTS,S/AS01 malaria candidate vaccine: a phase 2a controlled human malaria parasite infection and immunogenicity study. $J$ Infect Dis. 214(5):762-71

81. Osier FHA, Fegan G, Polley SD, Murungi L, Verra F, et al. 2008. Breadth and magnitude of antibody responses to multiple Plasmodium falciparum merozoite antigens are associated with protection from clinical malaria. Infect Immun. 76(5):2240-48

82. Osier FHA, Mackinnon MJ, Crosnier C, Fegan G, Kamuyu G, et al. 2014. New antigens for a multicomponent blood-stage malaria vaccine. Sci Transl Med. 6(247):247ra102-2

83. Fowkes FJI, Richards JS, Simpson JA, Beeson JG. 2010. The relationship between anti-merozoite antibodies and incidence of Plasmodium falciparum Malaria: a systematic review and meta-analysis. PLoS Med.7(1):e1000218

84. Cheng XJ, Hayasaka H, Watanabe K, Tao YL, Liu JY, et al. 2007. Production of high-affinity human monoclonal antibody Fab fragments to the 19-kilodalton Cterminal merozoite surface protein 1 of Plasmodium falciparum. Infect Immun. 75(7):3614-20

85. Stubbs J, Olugbile S, Saidou B, Simpore J, Corradin G, Lanzavecchia A. 2011. Strain-Transcending Fc-Dependent Killing of Plasmodium falciparum by Merozoite Surface Protein 2 Allele-Specific Human Antibodies. Infect Immun. 79(3):1143-52 
86. Maskus DJ, Królik M, Bethke S, Spiegel H, Kapelski S, et al. 2016. Characterization of a novel inhibitory human monoclonal antibody directed against Plasmodium falciparum Apical Membrane Antigen 1. Sci Rep, pp. 1-14

87. Beeson JG, Drew DR, Boyle MJ, Feng G, Fowkes FJI, Richards JS. 2016. Merozoite surface proteins in red blood cell invasion, immunity and vaccines against malaria. FEMS Microbiol. Rev. 40(3):343-72

88. Riley EM, Stewart VA. 2013. Immune mechanisms in malaria: new insights in vaccine development. Nat Med.19(2):168-78

89. Dvorak JA, Miller LH, Whitehouse WC, Shiroishi T. 1975. Invasion of erythrocytes by malaria merozoites. Science. 187(4178):748-50

90. Gilson PR, Crabb BS. 2009. Morphology and kinetics of the three distinct phases of red blood cell invasion by Plasmodium falciparum merozoites. Int J Parasitol. 39(1):91-96

91. Weiss GE, Crabb BS, Gilson PR. 2016. Overlaying molecular and temporal aspects of malaria parasite invasion. Trends Parasitol. 32(4):284-95

92. Cowman AF, Tonkin CJ, Tham W-H, Duraisingh MT. 2017. The molecular basis of erythrocyte invasion by malaria parasites., pp. 1-14

93. Boyle MJ, Langer C, Chan J-A, Hodder AN, Coppel RL, et al. 2014. Sequential processing of merozoite surface proteins during and after erythrocyte invasion by Plasmodium falciparum. Infect Immun. 82(3):924-36

94. Bruce MC, Galinski MR, Barnwell JW, Donnelly CA, Walmsley M, et al. 2000. Genetic diversity and dynamics of Plasmodium falciparum and $P$. vivax populations in multiply infected children with asymptomatic malaria infections in Papua New Guinea. Parasitology. 121(3):257-72

95. Henning L, Schellenberg D, Smith T, Henning D, Alonso P, et al. 2004. A prospective study of Plasmodium falciparum multiplicity of infection and morbidity in Tanzanian children. Trans $R$ Soc Trop Med Hyg. 98(12):687-94

96. Bendixen M, Msangeni HA, Pedersen, BV, Shayo D, Bodker R. 2001. Diversity of Plasmodium falciparum Populations and complexity of infections in relation to transmission intensity and host age: a study from the Usambara Mountains, Tanzania. Trans R Soc Trop Med Hyg. 95(2):143-48

97. Duncan CJA, Hill AVS, Ellis RD. 2014. Can growth inhibition assays (GIA) predict blood-stage malaria vaccine efficacy? Hum Vaccin Immunother. 8(6):706-14

98. Joos C, Marrama L, Polson HEJ, Corre S, Diatta A-M, et al. 2010. Clinical protection from falciparum malaria correlates with neutrophil respiratory bursts induced by merozoites opsonized with human serum antibodies. PLOS ONE. 5(3):e9871-13

99. Kapelski S, Klockenbring T, Fischer R, Barth S, Fendel R. 2014. Assessment of the neutrophilic antibody-dependent respiratory burst (ADRB) response to Plasmodium falciparum. J Leukoc Biol. 96(6):1131-42

100. Llewellyn D, Miura K, Fay MP, Williams AR, Murungi LM, et al. 2015. Standardization of the antibody-dependent respiratory burst assay with human neutrophils and Plasmodium falciparum malaria. Sci Rep, pp. 1-14

101. Osier FHA, Feng G, Boyle MJ, Langer C, Zhou J, et al. 2014. Opsonic phagocytosis of Plasmodium falciparum merozoites: mechanism in human immunity and a correlate of protection against malaria. BMC Med.12(1):108

102. Boyle MJ, Reiling L, Feng G, Langer C, Osier FHA, et al. 2015. Human antibodies fix complement to inhibit Plasmodium falciparum invasion of erythrocytes and are associated with protection against malaria. Immunity. 42(3):580-90 
103. Baum J, Chen L, Healer J, Lopaticki S, Boyle M, et al. 2009. Reticulocyte-binding protein homologue 5 - an essential adhesin involved in invasion of human erythrocytes by Plasmodium falciparum. Int J Parasitol. 39(3):371-80

104. Crosnier C, Bustamante LY, Bartholdson SJ, Bei AK, Theron M, et al. 2011. Basigin is a receptor essential for erythrocyte invasion by Plasmodium falciparum. Nature. 480(7378):534-37

105. Bustamante LY, Bartholdson SJ, Crosnier C, Campos MG, Wanaguru M, et al. 2013. A full-length recombinant Plasmodium falciparum PfRH5 protein induces inhibitory antibodies that are effective across common PfRH5 genetic variants. Vaccine. 31(2):373-79

106. Manske M, Miotto O, Campino S, Auburn S, Almagro-Garcia J, et al. 2012. Analysis of Plasmodium falciparum diversity in natural infections by deep sequencing. Nature. 487(7407):375-79

107. Williams AR, Douglas AD, Miura K, Illingworth JJ, Choudhary P, et al. 2012. Enhancing blockade of Plasmodium falciparum erythrocyte invasion: assessing combinations of antibodies against PfRH5 and other merozoite antigens. PLoS Pathog. 8(11):e1002991-15

108. Wright KE, Hjerrild KA, Bartlett J, Douglas AD, Jin J, et al. 2014. Structure of malaria invasion protein RH5 with erythrocyte basigin and blocking antibodies. Nat Med. 515(7527):427-30

109. Chen L, Lopaticki S, Riglar DT, Dekiwadia C, Uboldi AD, et al. 2011. An EGF-like protein forms a complex with PfRh5 and is required for invasion of human erythrocytes by Plasmodium falciparum. PLoS Pathog. 7(9):e1002199-19

110. Reddy KS, Amlabu E, Pandey AK, Mitra P, Chauhan VS, Gaur D. 2015. Multiprotein complex between the GPI-anchored CyRPA with PfRH5 and PfRipr is crucial for Plasmodium falciparum Erythrocyte invasion. Proc Natl Acad Sci USA. 112(4):1179-84

111. Volz JC, Yap A, Sisquella X, Thompson JK, Lim NTY, et al. 2016. Essential role of the PfRh5/PfRipr/CyRPA complex during Plasmodium falciparum Invasion of erythrocytes. Cell Host Microbe. 20(1):60-71

112. Galaway F, Drought LG, Fala M, Cross N, Kemp AC, et al. 2017. P113 is a merozoite surface protein that binds the $\mathrm{N}$ terminus of Plasmodium falciparum RH5. Nat Commun, pp. 1-11

113. Chiu CYH, Healer J, Thompson JK, Chen L, Kaul A, et al. 2014. Association of antibodies to Plasmodium falciparum reticulocyte binding protein homolog 5 with protection from clinical malaria. Front Microbiol. 5:314

114. Tran TM, Ongoiba A, Coursen J, Crosnier C, Diouf A, et al. 2014. Naturally acquired antibodies specific for Plasmodium falciparum reticulocyte-binding protein homologue 5 inhibit parasite growth and predict protection from malaria. $J$ Infect Dis. 209(5):789-98

115. Douglas AD, Baldeviano GC, Lucas CM, Lugo-Roman LA, Crosnier C, et al. 2015. A PfRH5-based vaccine is efficacious against heterologous strain blood-stage Plasmodium falciparum infection in Aotus monkeys. Cell Host Microbe. 17(1):13039

116. Srinivasan P, Ekanem E, Diouf A, Tonkin ML, Miura K, et al. 2014. Immunization with a functional protein complex required for erythrocyte invasion protects against lethal malaria. Proc Natl Acad Sci USA. 111(28):10311-16

117. Srinivasan P, Baldeviano GC, Miura K, Diouf A, Ventocilla JA, et al. 2017. A malaria vaccine protects Aotus monkeys against virulent Plasmodium falciparum infection. NPJ Vaccines, pp. 1-9 
118. Nunes JK, Woods C, Carter T, Raphael T, Morin MJ, et al. 2014. Development of a transmission-blocking malaria vaccine: Progress, challenges, and the path forward. Vaccine. 32(43):5531-39

119. Sinden RE. 2017. Developing transmission-blocking strategies for malaria control. PLoS Pathog. 13(7):e1006336-12

120. malERA consultative group on vaccines. 2011. A Research Agenda for Malaria Eradication: Vaccines. PLoS Med. 8(1):e1000398

121. Sauerwein RW, Bousema T. 2015. Transmission blocking malaria vaccines: assays and candidates in clinical development. Vaccine. 33(52):7476-82

122. Kapulu MC, Da DF, Miura K, Li Y, Blagborough AM, et al. 2015. Comparative assessment of transmission-blocking vaccine candidates against Plasmodium falciparum. Sci Rep. 5:11193

123. Molina-Cruz A, Garver LS, Alabaster A, Bangiolo L, Haile A, et al. 2013. The human malaria parasite $P f s 47$ gene mediates evasion of the mosquito immune system. Science. 340(6135):984-87

124. Carter R, Graves PM, Keister DB, Quakyi IA. 1990. Properties of epitopes of Pfs 48/45, a target of transmission blocking monoclonal antibodies, on gametes of different isolates of Plasmodium falciparum. Parasite Immunol. 12(6):587-603

125. Rener J. 1983. Target antigens of transmission-blocking immunity on gametes of plasmodium falciparum. J Exp Med. 158(3):976-81

126. Vermeulen AN. 1985. Sequential expression of antigens on sexual stages of Plasmodium falciparum Accessible to transmission-blocking antibodies in the mosquito. J Exp Med. 162(5):1460-76

127. Stone WJR, Campo JJ, Ouédraogo AL, Meerstein-Kessel L, Morlais I, et al. 2018. Unravelling the immune signature of Plasmodium falciparum transmission-reducing immunity. Nat Commun. 2018(FEB):1-14

128. Scally SW, McLeod B, Bosch A, Miura K, Liang Q, et al. 2017. Molecular definition of multiple sites of antibody inhibition of malaria transmission-blocking vaccine antigen Pfs25. Nat Commun. 8(1):1568

129. Baruch DI, Pasloske BL, Singh HB, Bi X, Ma XC, et al. 1995. Cloning the $P$. falciparum gene encoding PfEMP1, a malarial variant antigen and adherence receptor on the surface of parasitized human erythrocytes. Cell. 82(1):77-87

130. Smith JD, Chitnis CE, Craig AG, Roberts DJ, Hudson-Taylor DE, et al. 1995. Switches in expression of Plasmodium falciparum var genes correlate with changes in antigenic and cytoadherent phenotypes of infected erythrocytes. Cell. 82(1):10110

131. Fernandez V, Hommel M, Chen Q, Hagblom P, Wahlgren M. 1999. Small, clonally variant antigens expressed on the surface of the Plasmodium falciparum-infected erythrocyte are encoded by the Rif gene family and are the target of human immune responses. J Exp Med. 190(10):1393-1404

132. Kyes SA, Rowe JA, Kriek N, Newbold CI. 1999. Rifins: a second family of clonally variant proteins expressed on the surface of red cells infected with Plasmodium falciparum. Proc Natl Acad Sci USA. 96(16):9333-38

133. Kaviratne M, Khan SM, Jarra W, Preiser PR. 2002. Small variant STEVOR antigen is uniquely located within Maurer's clefts in Plasmodium falciparum-infected red blood cells. Eukaryot Cell. 1(6):926-35

134. Scherf A, Lopez-Rubio J-J, Riviere L. 2008. Antigenic variation in Plasmodium falciparum. Annu. Rev. Microbiol. 62(1):445-70 
135. Salanti A, Dahlback M, Turner L, Nielsen MA, Barfod L, et al. 2004. Evidence for the involvement of VAR2CSA in pregnancy-associated malaria. J Exp Med. 200(9):1197-1203

136. Rowe JA, Claessens A, Corrigan RA, Arman M. 2009. Adhesion of Plasmodium falciparum-infected erythrocytes to human cells: molecular mechanisms and therapeutic implications. Expert Rev. Mol.Med.11:e16

137. Turner L, Lavstsen T, Berger SS, Wang CW, Petersen JEV, et al. 2013. Severe malaria is associated with parasite binding to endothelial protein $\mathrm{C}$ receptor. Nature. 498(7455):502-5

138. Bull PC, Abdi AI. 2016. The role of PfEMP1 as targets of naturally acquired immunity to childhood malaria: prospects for a vaccine. Parasitology. 143(02):17186

139. Avril M, Tripathi AK, Brazier AJ, Andisi C, Janes JH, et al. 2012. A restricted subset of Var Genes mediates adherence of Plasmodium falciparum-infected erythrocytes to brain endothelial cells. Proc. Natl. Acad. Sci. U.S.A. 109(26):E1782-90

140. Claessens A, Adams Y, Ghumra A, Lindergard G, Buchan CC, et al. 2012. A subset of group A-like Var Genes encodes the malaria parasite ligands for binding to human brain endothelial cells. Proc. Natl. Acad. Sci. U.S.A. 109(26):10156-57

141. Azasi Y, Lindergard G, Ghumra A, Mu J, Miller LH, Rowe JA. 2018. Infected erythrocytes expressing DC13 PfEMP1 differ from recombinant proteins in EPCRbinding function. Proc. Natl. Acad. Sci. U.S.A. 115(5):1063-68

142. Avril M, Bernabeu M, Benjamin M, Brazier AJ, Smith JD. 2016. Interaction between endothelial protein $\mathrm{C}$ receptor and intercellular adhesion molecule 1 to mediate binding of Plasmodium falciparum-infected erythrocytes to endothelial cells. mBio. 7(4):e00615-16-10

143. Lennartz F, Adams Y, Bengtsson A, Olsen RW, Turner L, et al. 2017. Structureguided identification of a family of dual receptor-binding PfEMP1 that is associated with cerebral malaria. Cell Host Microbe. 21(3):403-14

144. Cunnington AJ, Riley EM, Walther M. 2013. Stuck in a rut? Reconsidering the role of parasite sequestration in severe malaria syndromes. Trends Parasitol. 29(12):58592

145. Fried M, Nosten F, Brockman A, Brabin BJ, Duffy PE. 1998. Maternal antibodies block malaria. Nature. 395(6705):851-52

146. Fried M, Duffy PE. 2015. Designing a VAR2CSA-based vaccine to prevent placental malaria. Vaccine. 33(52):7483-88

147. Magistrado P, Salanti A, Ndam NGT, Mwakalinga SB, Resende M, et al. 2008. VAR2CSA expression on the surface of placenta-derived Plasmodium falciparuminfected erythrocytes. J Infect Dis. 198(7):1071-74

148. McRobert L, Preiser P, Sharp S, Jarra W, Kaviratne M, et al. 2004. Distinct trafficking and localization of STEVOR proteins in three stages of the Plasmodium falciparum life cycle. Infect Immun. 72(11):6597-6602

149. Blythe JE, Yam XY, Kuss C, Bozdech Z, Holder AA, et al. 2008. Plasmodium falciparum STEVOR Proteins Are Highly Expressed in Patient Isolates and Located in the Surface Membranes of Infected Red Blood Cells and the Apical Tips of Merozoites. Infect Immun. 76(7):3329-36

150. Khattab A, Meri S. 2011. Exposure of the Plasmodium falciparum clonally variant STEVOR proteins on the merozoite surface. Malar J. 10(1):58

151. Florens L, Washburn MP, Raine JD, Anthony RM, Grainger M, et al. 2002. A proteomic view of the Plasmodium falciparum life cycle. Nature. 419(6906):520-26 
152. Petter M, Haeggström M, Khattab A, Fernandez V, Klinkert M-Q, Wahlgren M. 2007. Variant proteins of the Plasmodium falciparum RIFIN family show distinct subcellular localization and developmental expression patterns. Mol Biochem Parasitol. 156(1):51-61

153. Sanyal S, Egee S, Bouyer G, Perrot S, Safeukui I, et al. 2012. Plasmodium falciparum STEVOR proteins impact erythrocyte mechanical properties. Blood. 119(2):e1-e8

154. Niang M, Bei AK, Madnani KG, Pelly S, Dankwa S, et al. 2014. STEVOR Is a Plasmodium falciparum erythrocyte binding protein that mediates merozoite invasion and rosetting. Cell Host Microbe. 16(1):81-93

155. Niang M, Yan Yam X, Preiser PR. 2009. The Plasmodium falciparum STEVOR multigene family mediates antigenic variation of the infected erythrocyte. PLoS Pathog. 5(2):e1000307

156. Goel S, Palmkvist M, Moll K, Joannin N, Lara P, et al. 2015. RIFINs are adhesins implicated in severe Plasmodium falciparum Malaria. Nat Med. 21(4):314-17

157. Tan J, Pieper K, Piccoli L, Abdi A, Foglierini M, et al. 2016. A LAIR1 insertion generates broadly reactive antibodies against malaria variant antigens. Nature. 529(7584):105-9

158. Saito F, Hirayasu K, Satoh T, Wang CW, Lusingu J, et al. 2017. Immune evasion of Plasmodium falciparum by RIFIN via inhibitory receptors. Nat Med, pp. 1-22

159. Bull PC, Lowe BS, Kortok M, Molyneux CS, Newbold CI, Marsh K. 1998. Parasite antigens on the infected red cell surface are targets for naturally acquired immunity to malaria. Nat Med. 4(3):358-60

160. Giha HA, Staalsoe T, Dodoo D, Roper C, Satti GMH, et al. 2000. Antibodies to variable Plasmodium falciparum-infected erythrocyte surface antigens are associated with protection from novel malaria infections. Immunol Lett. 71(2):117-26

161. Duffy PE, Fried M. 2003. Antibodies that inhibit Plasmodium falciparum adhesion to chondroitin sulfate A are associated with increased birth weight and the gestational age of newborns. Infect Immun. 71(11):6620-23

162. Barfod L, Bernasconi NL, Dahlbäck M, Jarrossay D, Andersen PH, et al. 2006. Human pregnancy-associated malaria-specific B cells target polymorphic, conformational epitopes in VAR2CSA. Mol Microbiol. 63(2):335-47

163. Barfod L, Dobrilovic T, Magistrado P, Khunrae P, Viwami F, et al. 2010. Chondroitin sulfate A-adhering Plasmodium falciparum-infected erythrocytes express functionally important antibody epitopes shared by multiple variants. $J$ Immunol. 185(12):7553-61

164. Pehrson C, Salanti A, Theander TG, Nielsen MA. 2017. Pre-clinical and clinical development of the first placental malaria vaccine. Expert Rev Vaccines. 16(6):61324

165. Stanley HA, Mayes JT, Cooper NR, Reese RT. 1984. Complement activation by the surface of Plasmodium falciparum infected erythrocytes. Mol Immunol. 21(2):14550

166. Arora G, Hart GT, Manzella-Lapeira J, Doritchamou JYA, Narum DL, et al. 2018. NK cells inhibit Plasmodium falciparum Growth in red blood cells via antibodydependent cellular cytotoxicity. eLife. 7:

167. Teo A, Hasang W, Boeuf P, Rogerson S. 2015. A robust phagocytosis assay to evaluate the opsonic activity of antibodies against Plasmodium falciparum-infected erythrocytes. In Malaria Vaccines: Methods and Protocols, ed A Vaughan, pp. 14552. New York, NY: Springer New York. 8 p. 
168. Higgins MK, Carrington M. 2014. Sequence variation and structural conservation allows development of novel function and immune evasion in parasite surface protein families. Protein Sci. 23(4):354-65

169. Newbold CI, Pinches R, Roberts DJ, Marsh K. 1992. Plasmodium falciparum: the human agglutinating antibody response to the infected red cell surface is predominantly variant specific. Exp Parasitol. 75(3):281-92

170. Pieper K, Tan J, Piccoli L, Foglierini M, Barbieri S, et al. 2017. Public antibodies to malaria antigens generated by two LAIR1 insertion modalities. Nat Med. 548(7669):597-601

171. Hsieh F-L, Higgins MK. 2017. The structure of a LAIR1-containing human antibody reveals a novel mechanism of antigen recognition. eLife. 6:

172. Reed JH, Jackson J, Christ D, Goodnow CC. 2016. Clonal redemption of autoantibodies by somatic hypermutation away from self-reactivity during human immunization. J Exp Med. 213(7):1255-65

173. Jardine JG, Ota T, Sok D, Pauthner M, Kulp DW, et al. 2015. Priming a broadly neutralizing antibody response to HIV-1 using a germline-targeting immunogen. Science. 349(6244):156-61

174. Briney B, Sok D, Jardine JG, Kulp DW, Skog P, et al. 2016. Tailored immunogens direct affinity maturation toward HIV neutralizing antibodies. Cell. 166(6):14591464.e11 